\title{
Indigenous Lien Minh chicken of Vietnam: Phenotypic characteristics and single nucleotide polymorphisms of GH, IGFBP and PIT candidate genes related to growth traits
}

\author{
HUONG DO THI THU ${ }^{1}$, NGUYEN TRAN THI BINH ${ }^{2}$, LUC DO DUC ${ }^{2}$, DOAN BUI HUU ${ }^{2}$, \\ DANG THUY NHUNG ${ }^{2}$, CANH NGUYEN XUAN ${ }^{2}$, LINH NGUYEN VIET ${ }^{3}$, ANH NGUYEN THAI ${ }^{2}$, \\ MINH LUU QUANG ${ }^{4}$, DANG KIM PHAM ${ }^{2, v}$, THINH NGUYEN HOANG ${ }^{2, v v}$ \\ ${ }^{1}$ Bac Giang Agriculture and Forestry University. Bích Sơn, Việt Yên, Bắc Giang, Vietnam \\ ${ }^{2}$ Faculty of Animal Science, Vietnam National University of Agriculture. Trau Quy, Gia Lam, Hanoi, Vietnam. ”email: pkdang2000@yahoo.com; \\ vnhthinh@vnua.edu.vn \\ ${ }^{3}$ Institute of Biotechnology, Vietnam Academy of Science and Technology. Cau Giay, Hanoi, Vietnam \\ ${ }^{4}$ Ministry of Science and Technology. Hanoi, Vietnam
}

Manuscript received: 15 September 2020. Revision accepted: 22 October 2020.

\begin{abstract}
Thu HDT, Binh NTT, Duc LD, Huu DB, Nhung DT, Xuan CN, Viet LN, Thai AN, Quang ML, Pham DK, Hoang TN. 2020. Indigenous Lien Minh chicken of Vietnam: Phenotypic characteristics and single nucleotide polymorphisms of GH, IGFBP and PIT candidate genes related to growth traits. Biodiversitas 21: 5344-5352. Lien Minh chicken, a Vietnamese indigenous breed, has contributed importantly to the economic development of rural citizens in Cat $\mathrm{Ba}$ island, Hai Phong province due to its highly desired characteristics. However, Lien Minh chickens showed a slower growth rate when compared to other industrial chicken breeds. Therefore, the study aims at assessing the appearance characteristics and growth performance of 100 individuals Lien Minh chickens, and investigating the single nucleotide polymorphisms (SNPs) of candidate genes including GH, IGFBP and PIT, which might be associated with growth traits. Blood samples were collected from wing of Lien Minh chickens and used for DNA extraction. Genotyping by the PCR-RFLP method was then conducted. The allele frequencies were 0.97 and 0.03 for alleles A and G of GHi3 gene, respectively. For in IGFBP2 gene, allele frequencies were found as 0.47 for the A allele and 0.53 for $\mathrm{G}$ allele. The allele frequencies for PIT1 gene were recorded as $100 \%$ for allele B. These polymorphic loci (GHi3, PIT1, and IGFBP2) were followed by the Hardy-Weinberg equilibrium in the Lien Minh chicken population. These were the initial results, which could be used to analyze the correlation of molecular markers and growth traits in Lien Minh chickens.
\end{abstract}

Keywords: Growth traits, Lien Minh chicken, nucleotide polymorphism

\section{INTRODUCTION}

In Vietnam, poultry breeding contributed approximately $35 \%$ of the total income of farm households (Cuong et al 2010). Raising indigenous poultry breeds is a priority nowadays because of the active source of breeds, the quality of meat and eggs is delicious, suitable with Vietnamese tastes. Lien Minh chicken is an indigenous breed that has been researched and exploited in recent years. Morphology characteristics of Lien Minh chicken have not been fully and in detail studied yet and the growth traits rate of the Lien Minh chicken is relatively low compared to other chickens, bodyweight of mature hens at 28.7 weeks of age reached $2.25 \mathrm{~kg}$ (Doan et al. 2016).

Recently, improving economic traits in poultry stock, application of molecular genetics for selection and breeding have efficiency and will continue to contribute for increasing potential production and genetic gains (Ali et al. 2013). Production traits are among the most important economic traits in the poultry industry. Integrating QTLs, SNPs, sequencing technologies, and characterizing the candidate genes related to growth will offer opportunities for more efficient selection for high growth rate chicken.
To date, numerous candidate genes and quantitative trait loci (QTL) for growth traits have been characterized. Potential candidate genes associated with growth traits such as growth hormone (GH), the insulin-like growth factor-binding protein II gene (IGFBPII), and pituitary specific transcription factor-1 (Pit-1) has been discovered in several chicken breeds (Jiang et al. 2004; Nie et al. 2005; Khadem et al. 2010).

Growth hormone $(\mathrm{GH})$ is a polypeptide hormone, which was encoded by GH gene and was secreted from the anterior pituitary gland and then combined with the growth hormone receptor in the liver for forming the GH-GHRIGFs signal pathway, affects growth and metabolism rate of chicken development (Lau et al. 2007).

Significant associations between SNPs of GH gene polymorphisms and growth traits has been confirmed in several studies including body and drumstick weight at 6 weeks of age (Ghelghachi et al. 2013), body weight at 14 , $35,42,49,63,77$ days of age (Nie et al. 2005), at hatching, at 7,11,13,17 weeks of age (Tang et al. 2011) and at 2, 4, 6 weeks of age (Anh et al. 2015), bodyweight of Mia chicken at ages from 7 to 14 weeks and with ADG at 4-6; $6-8 ; 8-10 ; 10-12$ and 2-16 weeks (Thinh et al. 2019). 
The insulin-like growth factor-binding protein II gene (IGFBPII) is an important member of IGFBPs family which has many biological functions with the size of approximately $38 \mathrm{kbp}$ that is located on chromosome 7 . The association of the IGFBP-2 gene with growth traits was found. The haplotypes of IGFBPII gene were related to body weight at 7,14 , and 35 days of age, breast depth, carcass weight, and breast muscle weight ( $\mathrm{P} \leq 0.05)$. Significant and suggestive dominant effects of $\mathrm{H} 1 \mathrm{H} 5$ diplotype were detected for body weight at 7, 14, 21, 28, and 90 days of age (Nie et al. 2005). Jinghai Yellow chickens with AA genotype of IGFBPII had significantly heavier bodyweight, at hatch and 12 weeks of age, than those of the $A B$ genotype $(\mathrm{p}<0.05)$ (Zhao et al. 2015). The A allele had a positive effect on growth rate of 4-8 and 812 weeks in females but in males only affected on growth rate of 0-4 weeks (Sidadolog et al. 2013).

Growth is regulated by several genes, of which pituitary specific transcription factor-1 (Pit-1) is the most important, and it has been proved to bind growth hormone, prolactin, and transforming growth factor- $\beta$ genes that play the most pivotal role in controlling growth in chickens. Due to its crucial regulatory function and a variety of bioactivities, PIT1 has been regarded as a candidate gene for production performance (Jiang et al. 2004). The research results recorded 3 of 5 SNPs of the PIT1 gene were significantly associated with growth traits in White hybrids Recessive Rock x Xinghua (Nie et al. 2005). Substitution of C-> T on the intron 5 of the PIT1 gene has a high association with the weight of 6 weeks of age, wing weight, back muscle weight in commercial Iranian broilers (Zahra et al. 2011). The haplogroups showed a significant effect on body weight at 7 weeks of age in PB-1 chickens. In broiler chickens, there was a significant effect at one day, 2 and 7 weeks of age and in layer strain, there was a significant effect at one day, 6 and 7 weeks of age. The significant association of haplogroups and growth rate was found between 0 and 2 weeks in broiler strain and between $0,2,6$ and 7 weeks in layer strains (Bhattacharya et al. 2012).

As a result, the study aims to determine phenotypic characteristics and the growth performance and genetic polymorphism of $G H, I G F B P$ and PIT genes of native Lien Minh chicken. The utilization of the growth-related molecular markers makes it possible to carry out early selection of quality chickens.

\section{MATERIALS AND METHODS}

\section{Animals}

This study was carried out at the experimental farm, Vietnam National University of Agriculture (VNUA) for a period of 20 weeks. A total of 40 females and 60 males of purebred Lien Minh chickens were provided by Hai Phong Genetic Conservation Center. The animal was individually identified by leg tag. From 0 to 3 weeks of age, chickens were raised in floor pens. After that, they were allowed to go out for semi-grazing and given commercial feed (commercial corn-soybean diets meeting National Research Council requirements) and water ad libitum until 20 weeks of age.

\section{Morphological characteristics}

Color of plumage at different parts (neck, back, wings, tails), shank, shape, and size of comb, eye color, beak color, and earlobes color of the roosters and hens were visually observed and photographed at 20 weeks of age.

Bodyweight and dimensions of chickens were collected from 100 adult individuals (40 females and 60 males) at 20 weeks of age. Bodyweight and body sizes were measured by electronic scales (SCA-301 China, Max 5000 g, accuracy $\pm 0.01 \mathrm{~g}$ ) and tape measure (accuracy $\pm 0.01 \mathrm{~mm}$ ) respectively according to FAO standards (FAO 2012).

\section{DNA extraction and PCR amplification}

Blood samples were collected in anti-coagulant tubes with EDTA and stored at $4^{\circ} \mathrm{C}$. Genomic DNA was extracted using proteinase $\mathrm{K}$ digestion followed by phenolchloroform extraction and precipitation with ethanol. Two pairs of primers for the G1705A intron 3 of $\mathrm{GH}$ gene and intron 5 of PIT1 gene and other for G639A exon 3 of IGFBP gene (Nie et al. 2005) were used to amplify the gene fragments. Information on primers sequence and polymorphisms are shown in Table 1 .

PCR was performed in a $25 \mu \mathrm{l}$ reaction containing $1 \mathrm{x}$ PCR Buffer, $1.5 \mathrm{mM} \mathrm{MgCl} 2,1.25 \mathrm{mM}$ each dNTPs, $5 \mathrm{pM}$ primer, 1U Taq-polymerase (Fermentas), and $100 \mathrm{ng}$ genomic DNA. In PCR amplification, an initial denaturation at $94^{\circ} \mathrm{C}$ for three minutes followed by 35 cycles of denaturation at $94{ }^{\circ} \mathrm{C}$ for 45 seconds, annealing for 45 seconds, and extension at $72{ }^{\circ} \mathrm{C}$ for 90 seconds, and an additional extension of $72{ }^{\circ} \mathrm{C}$ for seven minutes were set. PCR products were digested with restriction enzymes (RE) overnight at $37^{\circ} \mathrm{C}$ for all enzymes except TaqI (at 65 ${ }^{\circ} \mathrm{C}$ ). The restriction fragments were separated on $2 \%$ agarose gel.

Table 1. Information for primers and polymorphisms

\begin{tabular}{cccccc}
\hline Gene & SNP & \multicolumn{1}{c}{ Primer sequence (5'-3') } & PCR-RFLP size (bp) & Annealing temperature $\left({ }^{\circ}\right.$ C) & Enzyme \\
\hline GH & G1705A & F: TCCCAGGCTGCGTTTTGTACTC & $429 / 295 / 134$ & 64 & EcoRV \\
& Intron 3 & R: ACGGGGGTGAGCCAGGACTG & & 60 & Bsh1236I \\
IGFBP & G639A & F: ACCGGTCTGAGAGCATCCTTG & $540 / 350 / 190$ & & 61 \\
& Exon 2 & R: GGGAAAAAGGGTGTGCAAAAG & & TaqI \\
PIT1 & Intron 5 & F: GGGGATTTTGCCACTTTAGGG & $599 / 467 / 132$ & & \\
& & R: TGGGTAAGGCTCTGGCACTGT & & & \\
\hline
\end{tabular}




\section{Statistical analyses}

The allele frequencies were calculated by counting method as: $\mathrm{p}=2(\mathrm{AA})+(\mathrm{AB}) / 2 \mathrm{~N}$ and $\mathrm{q}=2(\mathrm{BB})+(\mathrm{AB}) /$ $2 \mathrm{~N}$ where $\mathrm{p}=$ the frequency of allele $\mathrm{A}, \mathrm{q}=$ the frequency of allele $\mathrm{B}$ and $\mathrm{N}=$ the total number of chickens tested. The Hardy-Weinberg Equilibrium (HWE) was estimated using the method of Rodriguez et al. (2009).

\section{RESULTS AND DISCUSSION}

\section{Morphological features}

The morphological variants including plumage, comb, shank, earlobe color of Lien Minh chickens are shown in Figures 1 to 8 . Three main neck plumage colors (black gold, yellow, and red) were observed on the roosters (Figure 1), in which the red color is dominant. For the hen, two main colors of neck (black yellow, and gold color) were found in the study population.

The predominant back and wings of roosters are red, followed by orange and yellow (Figure 1) and tail color was black (Figure 2). Three main plumage colors found in hens are light yellow, light brown, and golden brown (Figure 3).

The observed results of neck plumage color were in agreement with those of Amnueysit et al. (2000), the author reported that the neck and wing plumage color had a few mixing from other colors such as red, black, and whiteyellow color. Back-plumage color and wing plumage color results were also similar to the result of Suphawadee et al (2019). A study of Daikwo et al. (2011) on the Dekina hen native chicken breed found that hens with brown plumage accounted for the highest percentage (41.8\%) of the chicken population surveyed.

Compared to other indigenous chicken breeds in Vietnam, the color of Lien Minh chicken has some differences. In the study of Moula et al. (2011), Ri rooster have five types of feather (tan, wheat, copper black, gold salmon, and silver salmon) and Ri hen chickens have six types of feather (tan, wheat, copper black, gold salmon, dark red and silver salmon). Ho chickens have five feather types (black with gold hackle, black copper, wheat, tan, and tricolor) (Duy et al. 2015).

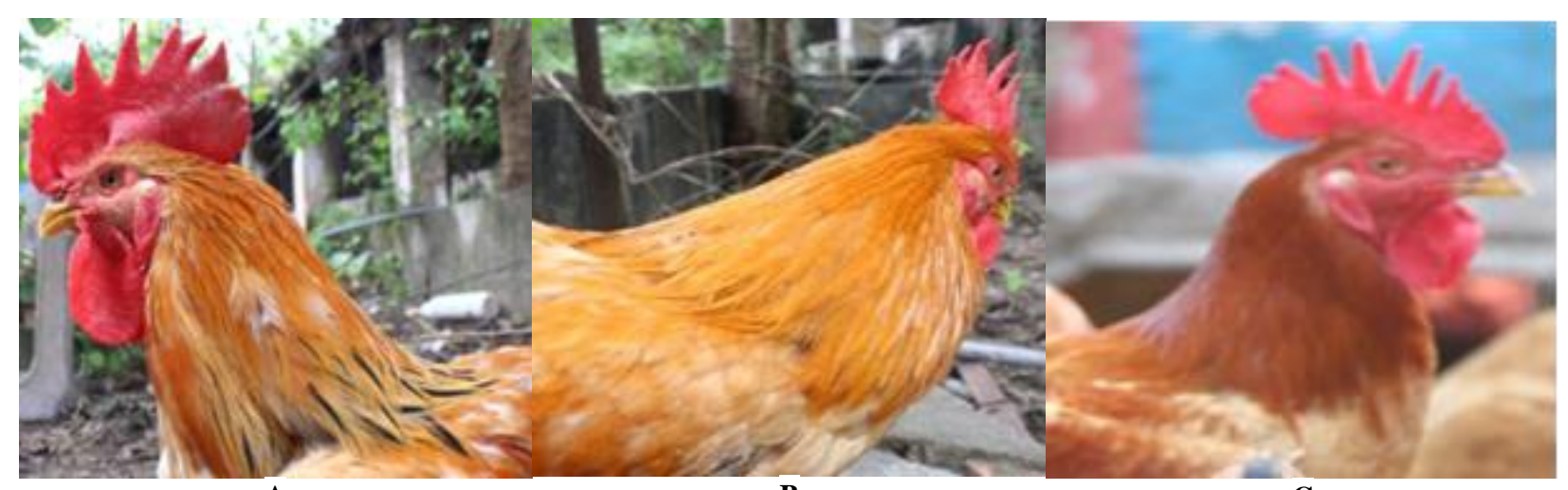

A

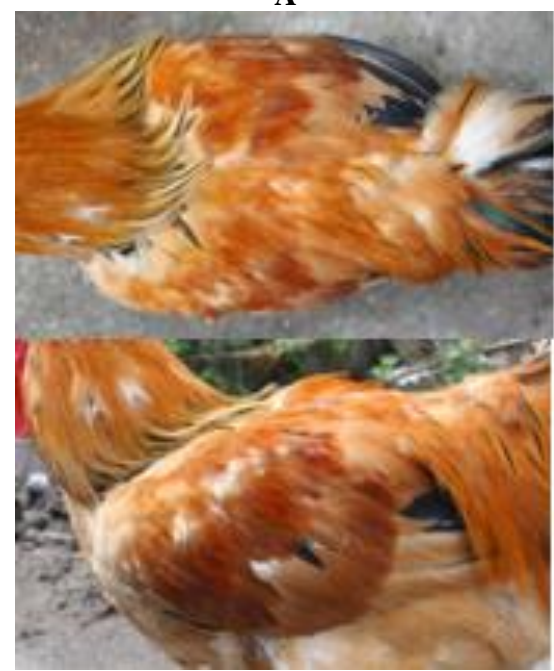

D

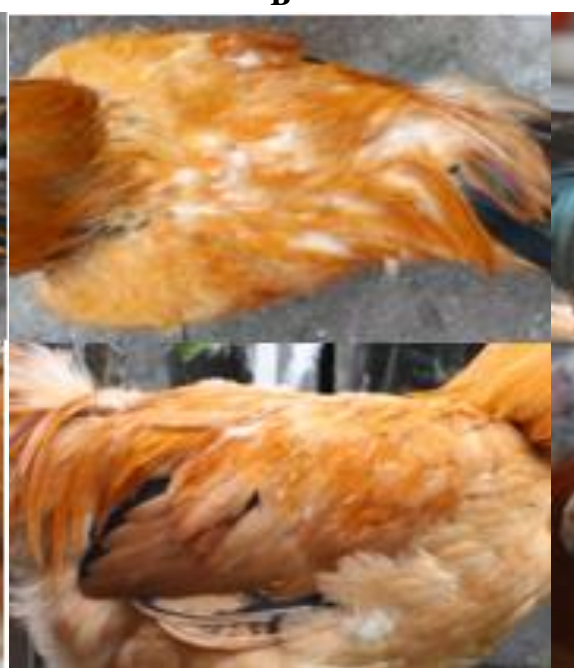

$\mathbf{E}$
C

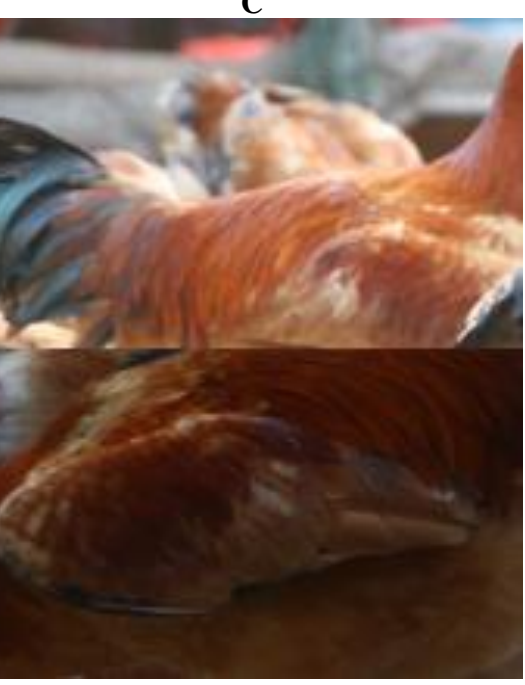

F

Figure 1. Neck, back and wing plumage color. A. Black gold; B. Yellow; C. Red; D. Orange; E. Yellow; F. Red 


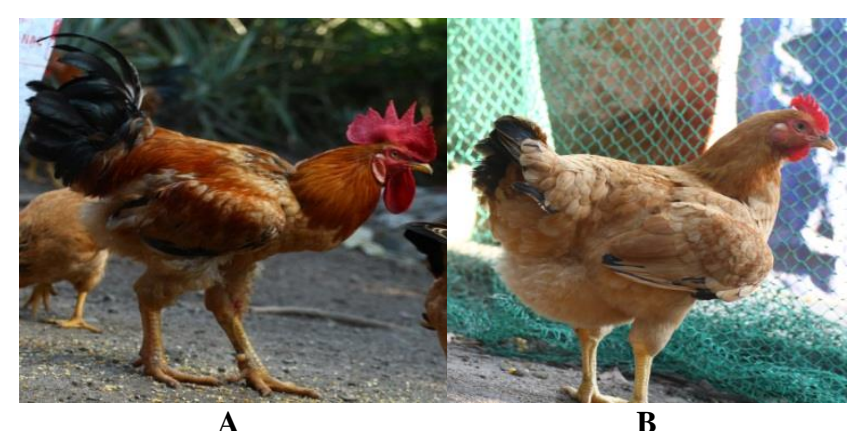

Figure 2. Black tail color. A. Rooster, B. Hen

For shank colors, 3 types of color were identified as ivory, light yellow, and orange, of which the hen's shank was mostly light yellow and ivory, and the rooster's shank was mostly orange (Figure 4). This result was similarly found on the Dekina native chicken breed (Daikwo et al. 2011), in which individuals with yellow shanks (40.5\%) accounted for a high proportion in the population, followed by black gold accounted for $37.25 \%$. The superiority of the yellow-shanked color was also observed by Cabarles et al. (2012) and Daikwo et al. (2011). However, Egahi et al.
(2010) reported that the predominance color of the shank was black in Nigerian local chicken.

For earlobes, two colors were observed, including red and silvery red (Figure 5). These results are respectively to earlobes of local chickens in Ethiopia with the red earlobes account for the highest proportion (Melesse and Negesse 2011).

The majority of Lien Minh chickens have bright red or dark red comb in roosters and red or light red in hens (Figure 6); comb sizes are available in small and medium sizes (hens); medium and large (roosters). The rooster has developed comb, dividing into 5-7 peaks. The comb of hen was also single but smaller than the comb of rooster. This result is similar to the report of Moula et al. (2011) that the color of the combs and the wattles were almost exclusively dark red in males and mainly red in females; comb peaks number varied between 5 and 8 in males and between 4 and 8 in females.

Accordingly, Daikwo et al. (2011) observed three types of single comb, beans, and roses; in which single comb accounts for over $50 \%$. The high diversity of comb types in male local Thai cock at Muang district, Phichit province had 11 varieties such as Hin, Au, Ja/Jak, Wong duan, Bae, NokTakrum, Dhog-GonKai, Dhog Chaba, Bye Sre, Tum and Pea (Amnueysit et al. 2000).

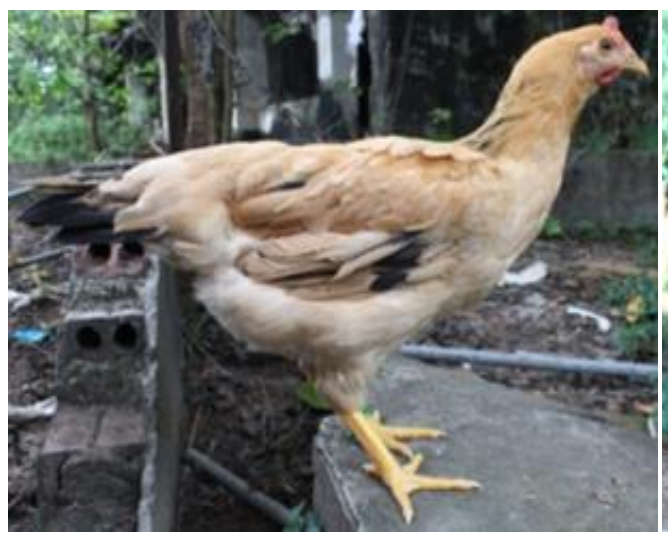

A

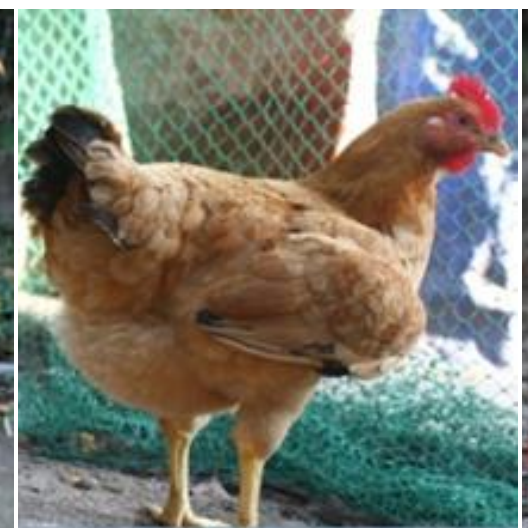

B

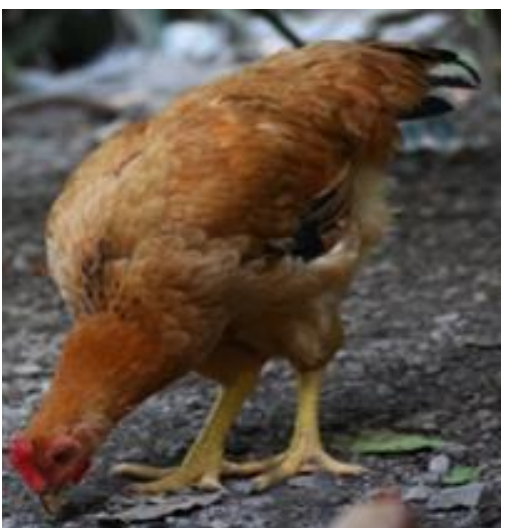

C

Figure 3. Hen plumage color. A. Light yellow, B. Light brown, C. Golden brown

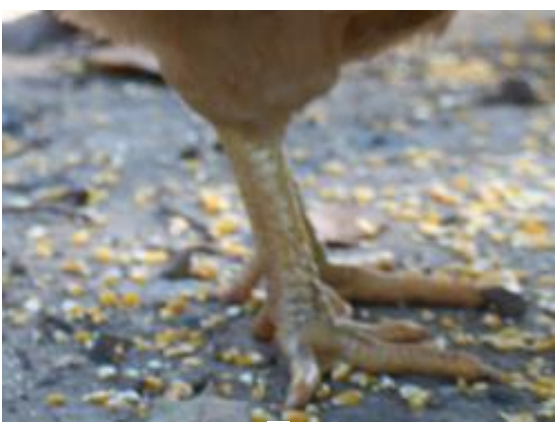

A

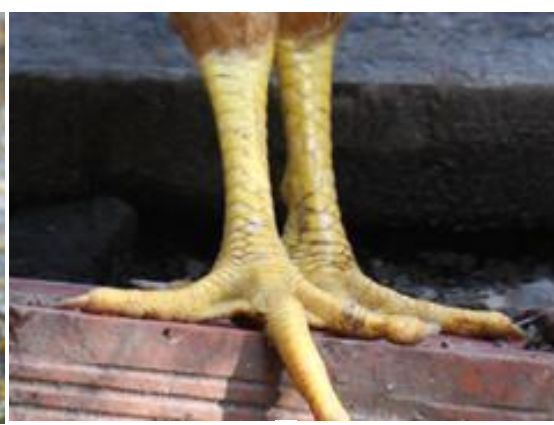

B

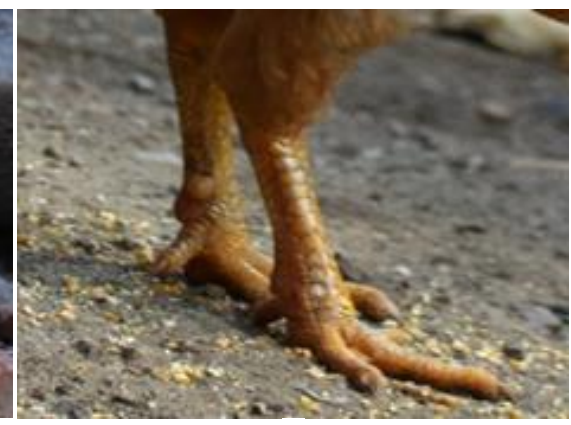

C

Figure 4. Shank color. A. Ivory gold, B. Light yellow, C. Orange 


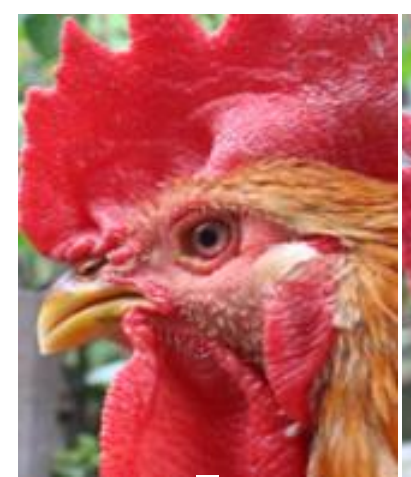

A

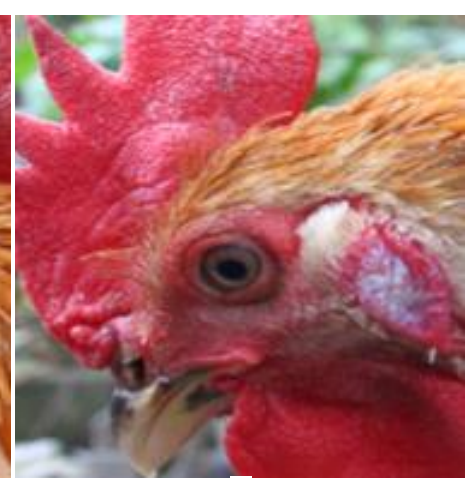

B
Figure 5. Earlobe color. A. Red, B. Silvery red

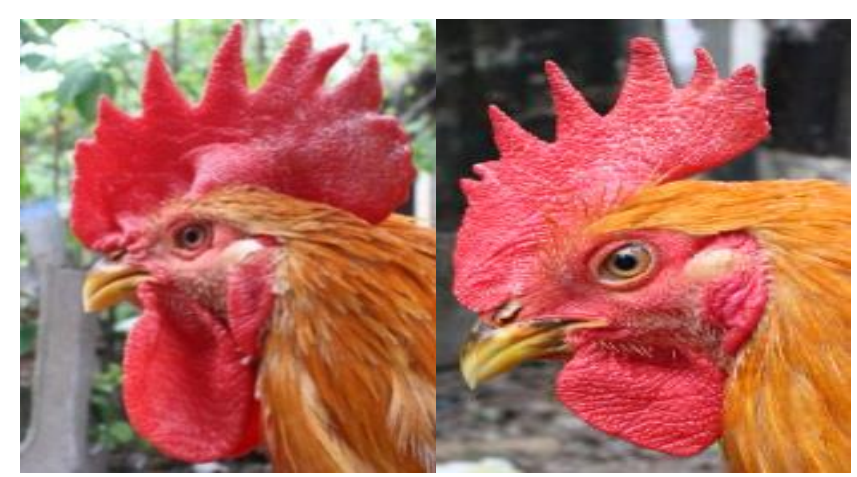

A

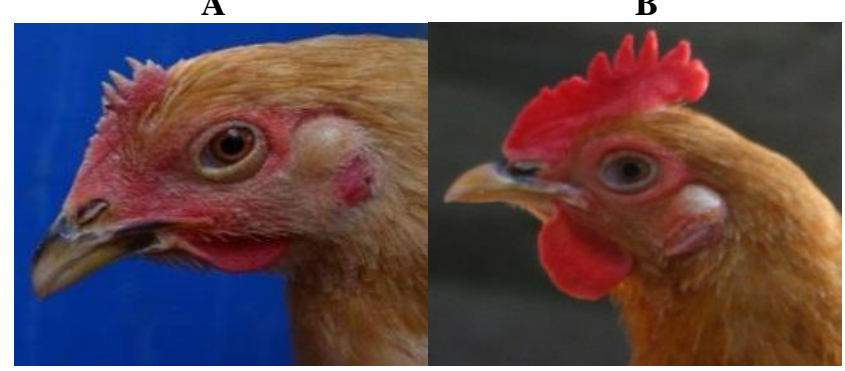

A

Figure 6. Shapes and sizes of comb. A-B. Single comb, medium and large in roosters, C-D. Small and medium in hens

For the beak color trait, three types of beak color were identified in population Lien Minh chicken including: yellow, black gold and black; in which black gold beak color is the most common, followed by yellow and black beak color (Figure 7). The color of the Lien Minh chicken is slightly different than that of some Vietnamese indigenous chickens such as $\mathrm{Ri}$ and Ho (dark horn and yellow) (Duy et al. 2015; Moula et al. 2011). According, Desta et al. (2013) also found in the Ethiopian chicken population that the beak color of the chicken was high diverse with yellow, white, yellow-brown, brown, and black.

The color of the eyes of Lien Minh chickens is also highly diverse, there are many different colors such as yellow, orange and brown, of which the orange eye was most predominant (Figure 8). In the report of Egahi et al (2010) on Nigeria indigenous chicken breeds, a variety of eye colors of this breed, with black-brown dominated at $37.9 \%$, followed by dark red and light brown. In another publication on indigenous chickens in Ethiopia, Aklilu et al. (2013) observed four eye colors (pearl, brown, orange and red), of which individuals with orange eyes accounted for the predominant proportion in the Horro chicken population $(87.8 \%)$ and Jarso $(72.5 \%)$.

\section{Bodyweight and dimensions}

The body weight and the body sizes of Lien Minh chickens are shown in Table 2. Bodyweight was significantly different between males and female $(\mathrm{P}<0.05)$. These results are in agreement with the results of Moula et al. (2011) in Ri chickens (1872.73 and $2085 \mathrm{~g}$, respectively). Indonesian Kedu chicken at 56 weeks of age showed that hens were heavier than Lien Minh chicken with the weight of Cemani chicken: $1.91 \mathrm{~kg}$; White Kedu: $1.68 \mathrm{~kg}$; Red Kedu: $1.84 \mathrm{~kg}$ and Black Kedu: $1.81 \mathrm{~kg}$. Male Kedu chickens exhibited a lower weight than Lien Minh chickens with a White Kedu weight of $1.73 \mathrm{~kg}$ and Black Kedu is $1.74 \mathrm{~kg}$, whereas the weight of Cemani is $2.12 \mathrm{~kg}$ and Red Kedu is 2.12 higher than Lien Minh chickens (Ismoyowati and

Susanto

2012).

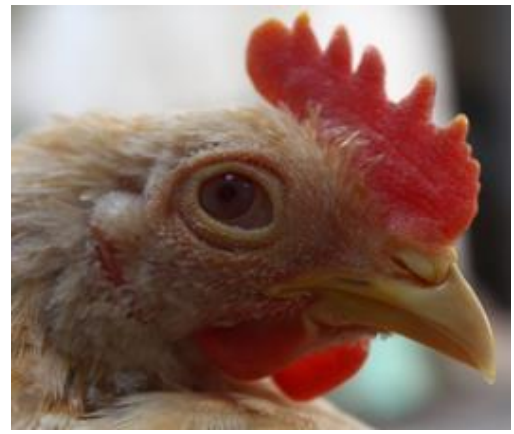

A

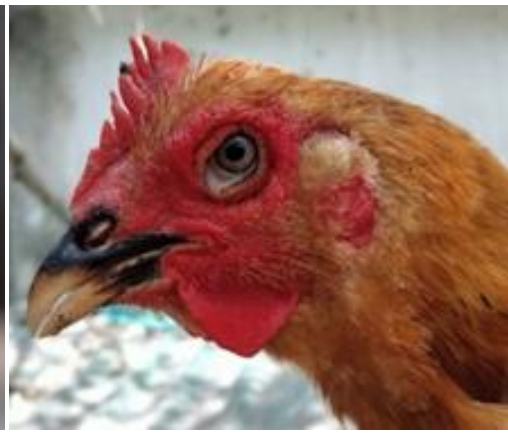

B

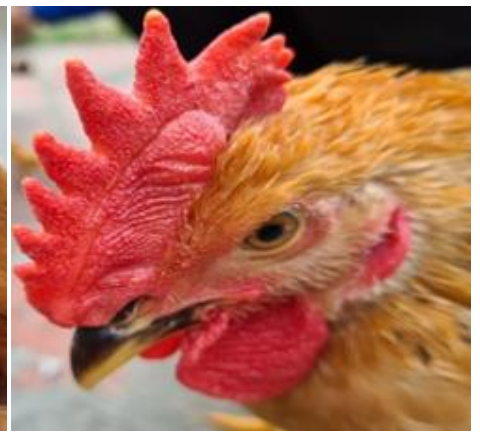

C

Figure 7. Beak color. A. Yellow, B. Black gold, C. Black 


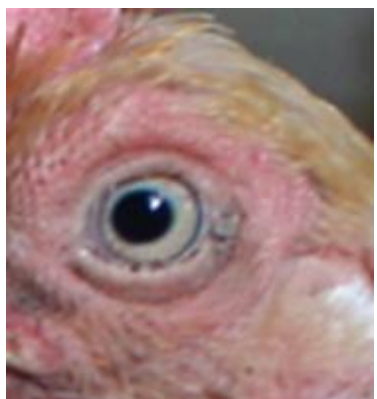

A

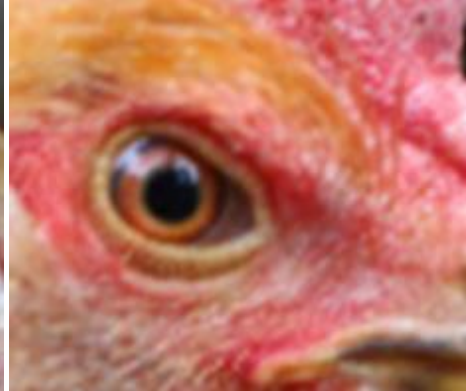

B

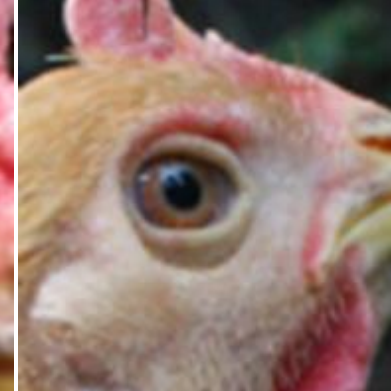

C

Figure 8. Eye color. A. Light yellow, B. Orange, C. Brown

Lien Minh chickens have well-proportioned, with average body size compared to other native chickens. The back length $(23.29 \mathrm{~cm})$, breast length $(15.00 \mathrm{~cm})$, thigh length $(12.08 \mathrm{~cm})$, thoracic perimeter $(25.01 \mathrm{~cm})$ and wing length $(22.28 \mathrm{~cm})$ of Lien Minh chickens were significantly different between males and females $(\mathrm{P}<0.05)$. These results smaller than those of Ho chickens $(22.45-26.07 \mathrm{~cm}$, $17.32-21.05 \mathrm{~cm}, 16.03-19.84 \mathrm{~cm}, 33.30-36.13 \mathrm{~cm}, 22.72-$ $26.94 \mathrm{~cm}$ respectively) (Duy et al. 2015). The back length, thoracic perimeter of Lien Minh chickens also slightly smaller than those of Ri chickens (23.43-27 cm, 29.09$31.73 \mathrm{~cm}$ respectively) (Moula et al. 2011). However, Lien Minh chickens are taller than other native chickens. That is shown in the shank length $(9.28 \mathrm{~cm}$ and longer than those of Ho chickens: 7.56-9.78 cm) (Duy et al. 2015). The average weight and size of Lien Minh chickens are also consistent with the development history of this breed. This is a chicken breed originating in Lien Minh village, Cat Ba islands; raised with the main condition of grazing and finding food on the island. Therefore, their weight and size are quite small compared to other domestic chicken breeds in the country.

\section{Genotypic and allelic frequencies \\ PCR-RFLP analysis}

Figure 9 shows the results of the PCR-RFLP analysis of the candidate genes. Bands in the gels represent the distinguishable genotypes in each of the polymorphisms observed. Briefly, two genotypes were found at the sites of $G H / E c o R V$ (AA, AG), three genotypes at the sites of IGFBP/Bsh1236I (AA, AG, GG) and one genotype at PIT/TaqI.

The SNPs of the GH gene were genotyped after digestion of the PCR products with the restriction enzyme $E c o R V$. The restriction fragment lengths for the A and G alleles of the GH/EcoRV locus were 429 and 295/134 bp. For the polymorphism in the IGFBP gene, the PCR product resulted in one DNA band with the molecular sizes of 540 bp. The IGFBP gene contained one cut site with Bsh1236I, the products were separated on $2 \%$ agarose for the two types of cutting the sizes were $540 \mathrm{bp}$ or $350 / 190 \mathrm{bp}$, corresponding to the $\mathrm{A}$ and $\mathrm{G}$ alleles, respectively. The following DNA restriction fragment was obtained for the PIT/TaqI, there is only one allele 599 bp for the AA genotype (Figure 9).

\section{Genotypic and allelic frequencies of GH, IGFBP, PIT genes}

Genotypic and allelic frequencies of the loci tested are presented in Table 3. In this study, three single nucleotide polymorphisms (SNPs) were identified from Lien Minh chickens. The results also showed that the observed distribution of genotypes in all three loci $(G H, I G F B P$, $P I T)$ was not significantly different from the distribution expected under the assumption of Hardy Weinberg equilibrium $(\mathrm{P}>0.05)$.

For the GH, the number of Lien Minh chickens that had $\mathrm{G}$ allele accounted for a low proportion of the population (0.03). The frequency of allele $\mathrm{G}$ of $\mathrm{GH}$ appears to be quite different in chicken breeds. Analysis of SNPs located in GH carried out by many studies showed that a highfrequency of the $\mathrm{G}$ allele in chickens gave a better growth trait. Specifically, Thai broiler chickens have GG genotype appeared with a high frequency of $49.75 \%$. On the other hand, frequency of AA only accounted for $6.62 \%$ (Anh et al. 2015). A similar frequency was found in the second generation of White Recessive Rock and Xinghua chickens; the AA genotype only appeared with a frequency of $4 \%$ (Nie et al. 2005). Studies on Coob500 and Hubbard chickens also showed similar results, in which the frequency of AA genotypes accounted for only $7.06 \%$ on Coob chickens and $2.11 \%$ on Hubbard breeds (Bassam et al. 2016). Therefore, it can be seen that the GG genotype in GHi3 polymorphism is considered as an indicator of application in broiler breeder selection.

For the IGFBP2 polymorphism in Lien Minh chickens in this study, the AG genotype appeared with the highest frequency (0.51), and the AA and GG genotypes had a similar frequency of occurrence, respectively 0.22 and 0.27 , the frequency of distribution of this genotype follows Hardy Weinberg's. Similar frequency distribution of A and $\mathrm{G}$ alleles on Mazandaran indigenous chicken populations were 0.37 and 0.63, respectively (Khadem et al. 2010). However, the results of genotypic frequencies in the study are different from those results of Khoa (2012). Specifically, the GG genotype with the highest frequency in all populations of Tau Vang chicken, Noi chicken, and Cobb 500 chicken was $0.69 ; 0.71$, and 0.74 . The AA genotype has a much lower frequency than the other two genotypes, especially in the Noi chicken population. This difference may be due to the genetic variation between the 
chicken populations. However, in Lien Minh chicken at this site (IGFBP/TaqI) only appeared one genotype AA.
Thus, IGFBP/TaqI can not be considered a candidate gene for growth traits in Lien Minh chickens.

Table 2. Bodyweight and body sizes of adult Lien Minh chickens of Vietnam

\begin{tabular}{|c|c|c|c|c|c|c|}
\hline \multirow{2}{*}{ Traits } & \multicolumn{2}{|c|}{ Male $(n=60)$} & \multicolumn{2}{|c|}{ Female $(n=40)$} & \multicolumn{2}{|c|}{ Overall $(n=100)$} \\
\hline & Mean & SD & Mean & SD & Mean & SD \\
\hline Bodyweight (g) & $2166.20^{*}$ & 114.27 & $1690.81^{*}$ & 144.86 & 1810.81 & 186.34 \\
\hline Back length $(\mathrm{cm})$ & $23.48^{*}$ & 3.10 & $22.50^{*}$ & 1.48 & 23.29 & 1.91 \\
\hline Breast length $(\mathrm{cm})$ & 14.99 & 2.13 & 14.51 & 1.20 & 15.00 & 1.41 \\
\hline Wing length (cm) & 22.60 & 1.57 & 21.90 & 3.98 & 22.28 & 3.09 \\
\hline Shank length $(\mathrm{cm})$ & 9.38 & 1.80 & 8.97 & 1.41 & 9.28 & 1.44 \\
\hline Thigh length $(\mathrm{cm})$ & 12.17 & 1.79 & 11.40 & 2.24 & 12.08 & 1.88 \\
\hline Thoracic perimeter $(\mathrm{cm})$ & $25.35^{*}$ & 3.41 & $24.39^{*}$ & 2.38 & 25.01 & 2.39 \\
\hline Chest depth $(\mathrm{cm})$ & $11.75^{*}$ & 1.61 & $10.67^{*}$ & 1.41 & 11.90 & 1.24 \\
\hline Shank circumference $(\mathrm{cm})$ & 4.92 & 0.75 & 4.29 & 0.37 & 4.71 & 0.61 \\
\hline
\end{tabular}

- Note: $*: P<0.05$

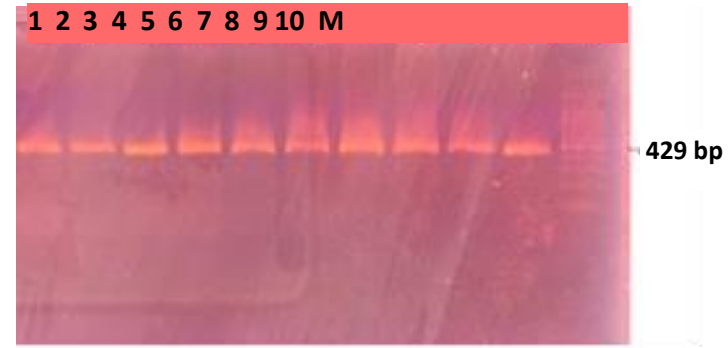

A. PCR products gene GHi3 (429bp)

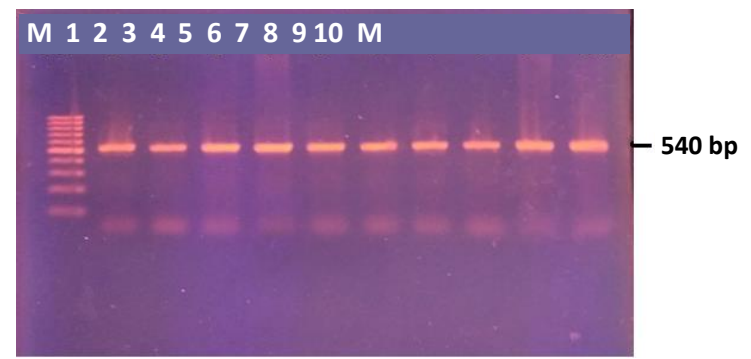

C. PCR products gene IGFBP2 (540 bp)

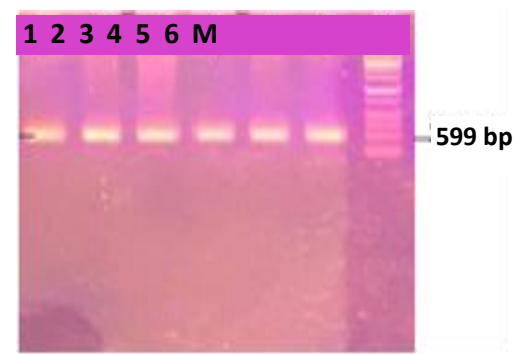

E. PCR products gene PIT1 (599 bp)

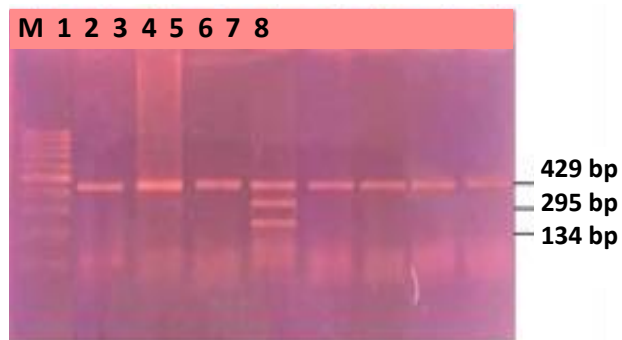

B. GHi3/ EcoRV: GG: 429 bp; AG: 429/295/134 bp

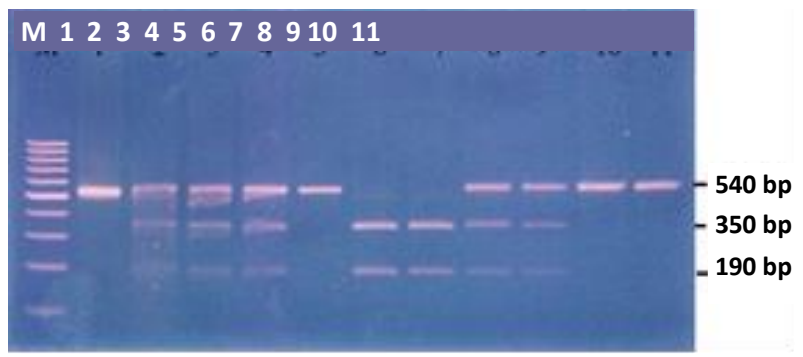

D. IGFBP2/Bsh1236I: AA: 540 bp; AG: 540/350/190 bp; GG: 350/190 bp

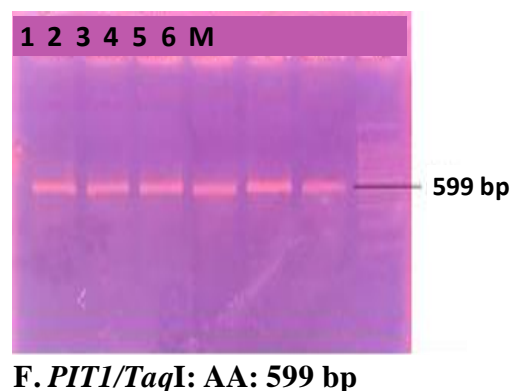

Figure 9. The PCR-RFLP analysis of the candidate genes. A, B. PCR-RFLP analysis of GHi3 gene; C, D. PCR-RFLP analysis of $I G F B P 2$ gene; E, F. PCR-RFLP analysis of PIT1 gene 
Table 3. Allele and genotype frequencies of genes in Lien Minh chicken of Vietnam

\begin{tabular}{|c|c|c|c|c|c|c|c|c|c|c|}
\hline \multirow{2}{*}{ Locus } & \multirow{2}{*}{$\mathbf{n}$} & \multicolumn{5}{|c|}{ Observed population } & \multicolumn{3}{|c|}{ Expected population } & \multirow{3}{*}{$\begin{array}{c}\text { HWE } \\
\chi^{2} \cdot P \\
0360.84^{\mathrm{ns}}\end{array}$} \\
\hline & & \multicolumn{3}{|c|}{ Genotype } & \multicolumn{2}{|c|}{ Allele } & \multicolumn{3}{|c|}{ Genotype } & \\
\hline GHi3 & 100 & AA & $\mathrm{AG}$ & GG & $\mathrm{A}$ & $\mathrm{G}$ & AA & $\mathrm{AG}$ & GG & \\
\hline & & 0.94 & 0.06 & 0.00 & 0.97 & 0.03 & 0.94 & 0.06 & 0 & \\
\hline$I G F B P 2$ & 100 & AA & AG & GG & A & $\mathrm{G}$ & AA & AG & GG & $0.050 .98^{\mathrm{ns}}$ \\
\hline & & 0.22 & 0.51 & 0.27 & 0.47 & 0.53 & 0.23 & 0.50 & 0.28 & \\
\hline PIT1 & 100 & AA & $\mathrm{AB}$ & $\mathrm{BB}$ & A & B & AA & $\mathrm{AB}$ & $\mathrm{BB}$ & $0.00 \mathrm{~ns}$ \\
\hline
\end{tabular}

In conclusion, our analysis examined phenotypic characteristics and the polymorphisms of three candidate genes in Lien Minh chickens. The observed distribution of the genotypes in three loci (GH, IGFBP, and PIT) were not significantly different from the distribution expected under the assumption of Hardy Weinberg equilibrium $(\mathrm{P}>0.05)$. Two of these loci (GH, IGFBP) should be used for the purpose of association studies between genotype/allele and growth traits in Lien Minh chickens.

\section{ACKNOWLEDGEMENTS}

This study was funded from a grant of scientific research of the Ministry of Agriculture and Rural Development and Vietnam National University of Agricultural (T2019-12-31VB)

\section{REFERENCES}

Aklilu E, Kebede K, Dessie T, Banerjee AK. 2013. Phenotypic Characterization of Indigenous Chicken Population in Ethiopia. Int $\mathbf{J}$ Interdiscip Multidiscip Stud 1 (1): 24-32.

Ali A, Javed K, Akram M, Pasha HM, Ahmad S. 2013. Detection of polymorphism of Insulin-like growth factor-I (IGF-I) gene in native Aseel chicken breed of Pakistan using PCR-RFLP. Agric Adv 2: 173176. DOI: 10.14196/AA.V2I6.864.

Amnueysit P, Amnueysit K, Toumsakul S. 2000. Diversity of Thai Roosters at Amphur Muang Pichit Province Breeds of Cocks. In: 38th Kasetsart University Annual Conference. 1-4 February 2000.

Anh NTL, Kunhareang S, Duangjinda M. 2015. Association of chicken growth hormones and insulin-like growth factor gene polymorphisms with growth performance and carcass traits in Thai broilers. AsianAustralasian J Anim Sci 28 (12): 1686. DOI: 10.5713/ajas.15.0028.

Bassam GM. Al-khatib, Dihya HH. Al-Hassani. 2016. Effect of G1705A SNP in Growth Hormone Gene on the Productive and Physiological Performance in Broiler Chicken. Iraqi J Biot 15 (1): 33-45.

Bhattacharya TK, Chatterjee RN, Priyanka M. 2012. Polymorphisms of Pit-1 gene and its association with growth traits in chicken. Poult Sci 91: 1057-1064. DOI: 10.3382/ps.2011-01990.

Cabarles J, Lambio AL, Vegaa SA, Capitan SS, Mendioro M. 2012. Distinct morphological features of traditional chickens (Gallus gallus domesticus) in Western Visayas, Philippines. Anim Genet Resour Informat 51: 73-87. DOI: 10.1017/S2078633612000410.

Cuong VC. 2010. Characteristics of the backyard poultry system in Vietnam. J Anim Sci Technol 26: 60-71.

Daikwo IS, Okpe AA, Ocheja JO. 2011. Phenotypic characterization of local chickens in Dekina. Int J Poult Sci 10 (6): 444-447. DOI: 10.3923/ijps.2011.444.447.

Desta TT, Dessie T, Bettridge J, Lynch SE, Melese K, Collins M, Mwacharo JM. 2013. Signature of artificial selection and ecological landscape on morphological structures of Ethiopian village chickens. Anim Genet Resour 52: 17-29. DOI: 10.1017/S2078633613000064.
Doan DH, Dang PK, Tuan HA, Thinh NH. 2016. Lien Minh chicken breed and live hood of people on district island Cat Hai of Hai Phong city, Viet Nam: Characterization oand prospects. J Anim Husb Sci Tech (JAHST) 209: 26-31.

Duy NV, Nassim M, Luc DD, Dang PK, Hiep DT, Doan BH, Ton VD, Farnir F. 2015. Ho Chicken in Bac Ninh Province (Vietnam): From an indigenous chicken to local poultry breed. Int J Poult Sci 14 (9): 521-528. DOI: 10.3923/ijps.2015.521.528.

Egahi JO, Dim NI, Momoh OM, Gwaza DS. 2010. Variations in qualitative traits in the Nigerian local chicken. Int J Poult Sci 9: 978979. DOI: 10.3923/ijps.2010.978.979.

FAO. 2012. Phenotypic characterization of animal genetic resources, fao animal production and health. Food and Agriculture Organization of United Nations, Rome.

Ghelghachi AA, Seyedabadi HR, Lak A. 2013. Association of growth hormone gene polymorphism with growth and fatness traits in Arian Broiler. Int J Biosci 3 (12): 216-220. DOI: 10.12692/ijb/3.12.216220.

Ismoyowati S, Susanto A. 2012. Genetic diversity of Kedu chicken based on phenotypic characteristics and microsatellite loci. Intl J Poult Sci 11 (9): 605-610. DOI: 10.3923/ijps.2012.605.610.

Jiang R, Li J, Qu L, Li, Yang N. 2004. A new single nucleotide polymorphism in the chicken pituitary-specific transcription factor (POU1F1) gene associated with growth rate. Anim Genet 35: 344346. DOI: 10.1111/j.1365-2052.2004.01164.x.

Khadem A, Hafezian H, Rahimi-Mianji G. 2010. Association of single nucleotide polymorphisms in IGFI, IGF-II and IGFBP-II with production traits in breeder hens of Mazandaran native fowls breeding station. Afr J Biot 9 (6): 805-810. DOI: 10.5897/AJB09.1231.

Khoa DVA. 2012. Effect of C1032T point mutation on IGFBP2 gene on meat yield traits in Tau Vang chickens, J Sci Can Tho University 24 (b): 1-7.

Lau JS. 2007. Cloning and characterization of chicken growth hormone binding protein (cGHBP). Domest Anim Endocrinol 33 (1): 107-121. DOI: 10.1016/j.domaniend.2006.04.012.

Melesse A, Negesse T. 2011. Phenotypic and morphological characterization of indigenous chicken populations in southern region of Ethiopia. Anim Genet Resour 49: 19-31. DOI: https://doi.org/10.1017/S207863361 1000099.

Moula, Luc DD, Dang PK, Farnir F, Ton VD, Binh DV, Leroy P, Nicolas A. 2011. The Ri chicken breed and livelihoods in North Vietnam characterisation and prospects. J Agric Rural Dev Trop Subtrop 112 (1): 57-69.

Nie Q, Lei M, Ouyang J, Zeng H, Tang G, Zhang X. 2005. Identification and characterization of single nucleotide polymorphisms in 12 chicken growth-correlated genes by denaturing high-performance liquid chromatography. Genet Sel Evol 37: 339-360. DOI: $10.1186 / 1297-9686-37-4-339$

Rodriguez S, Gaunt TR, Day INM. 2009. Hardy-Weinberg equilibrium testing of biological ascertainment for Mendelian randomization studies. Am J Epidemiol 169: 505. DOI: 10.1093/aje/kwn359

Sidadolog J, Artama W, Maharani D. 2013. The effect of insulin-like growth factor binding protein 2 gene on kampung chicken growth rate. Int J Poult Sci 12: 495. DOI: 10.3923/ijps.2013.495.500.

Suphawadee Y, Tuan NN. 2019. Diversity of phenotypic characteristics of White Tailed-Yellow Chicken populations reared under free-range system in Phitsanulok Province, Thailand. Biodiversitas 20 (5): 12711280. DOI: $10.13057 /$ biodiv/d200517.

Tang S, Ou J, Sun D, Zhang Y, Xu G. 2011. A novel 62-bp indel mutation in the promoter region of transforming growth factor-beta 2 (TGFB2) 
gene is associated with body weight in chickens. Anim Genet 42 (1): 108-112. DOI: 10.1111/j.1365-2052.2010.02060.x.

Thinh NH, Tuan HA, Vinh NT, Doan BH, Giang NTP, Farnir F, Nassim M, Linh NV, Dang PK. 2019. Association of single nucleotide polymorphisms in the insulin and growth hormone gene with growth traits of Mia Chicken. Indian J Anim Res 54 (6): 661-666. DOI: 10.18805/ijar.B-955.

Zahra R, Masoud A, Hamid RS, Cyrus A. 2011. Identification of a single nucleotide polymorphism of the pituitary-specific transcriptional factor 1 (Pit 1) gene and its association with body composition trait in Iranian commercial broiler line. Afr J Biotechnol 10 (60): 1297912983. DOI: $10.5897 / A J B 11.1149$.

Zhao XH, Li MY, Xu SS, Liu GJ. 2015. Single nucleotide polymorphisms in IGFBP-2 gene and their associations with body weight traits on Jinghai Yellow chicken. Braz J Poult Sci 17 (4): 497-502. DOI: 10.1590/1516-635X1704497-502 